\title{
Characteristics of a black coral meadow in the twilight zone of the central Mediterranean Sea
}

\author{
M. Bo ${ }^{1, *}$, G. Bavestrello ${ }^{1}$, S. Canese ${ }^{2}$, M. Giusti ${ }^{2}$, E. Salvati ${ }^{2}$, \\ M. Angiolilloº ${ }^{2}$ S. Greco ${ }^{2}$ \\ ${ }^{1}$ Dipartimento di Scienze del Mare, Università Politecnica delle Marche, Ancona, 60131, Italy \\ ${ }^{2}$ Istituto Superiore per la Protezione e la Ricerca Ambientale (ISPRA, formerly ICRAM), Via di Casalotti 300, Roma, 00166, Italy
}

\begin{abstract}
The hard substrata of the Mediterranean twilight zone commonly host the large, white, branched Antipathella subpinnata (Antipatharia, Myriopathidae). We discovered one of the largest populations of this black coral ever recorded in the Mediterranean Sea, forming a meadow of thousands of colonies in the deep waters off the Calabrian coast (South Italy, Tyrrhenian Sea). The meadow extends from 50 to $100 \mathrm{~m}$ depth and is a mixed assemblage of black coral and gorgonian colonies showing specific bathymetric ranges. Antipatharians inhabit the northern slopes of the explored rocky pinnacles receiving the northward moving current of the Strait of Messina. Up to $44 \%$ of the black corals are colonized by several encrusting epibionts. A. subpinnata deserves protection since it creates an important 3-dimensional habitat and represents the most characteristic component of the lower fringe of the circalittoral twilight environment in the Mediterranean Sea.
\end{abstract}

KEY WORDS: Black corals · Deep corals $\cdot$ Population structure $\cdot$ Twilight zone $\cdot$ ROV imaging Resale or republication not permitted without written consent of the publisher

\section{INTRODUCTION}

Research on deep coral assemblages in the Mediterranean Sea has been limited to the scleractinian coral banks mainly composed of the genera Lophelia and Madrepora (Tursi et al. 2004, Taviani et al. 2005), while the populations of black corals and gorgonians are almost unknown. These populations represent important 3-dimensional habitats hosting a rich associated fauna and attracting numerous species of commercial interest. Commercial fishing activities directly damage these corals that are particularly vulnerable because of their arborescent morphology and generally low growth rate. Data about the population structure of deep-water corals are therefore essential to assess the impact of commercial fisheries (Mortensen \& BuhlMortensen 2004).

Within non-scleractinian corals, antipatharians represent one of the least studied groups. Five species, belonging to 4 genera and 4 families, are known from the Mediterranean Sea: Antipathes dichotoma Pallas, 1766, A. fragilis Gravier, 1918 (Antipathidae), Paran- tipathes larix (Esper, 1790) (Schizopathidae), Leiopathes glaberrima (Esper, 1792) (Leiopathidae) and Antipathella subpinnata (Ellis and Solander, 1786) (Myriopathidae) (Opresko \& Försterra 2004). None of these species have ever been collected at depths shallower than $50 \mathrm{~m}$, while the majority occurs between 200 and $600 \mathrm{~m}$ depth on rock substrates. No species has ever been found on soft bottoms (Opresko \& Försterra 2004).

Antipathella subpinnata is a large, white, branched antipatharian with an Atlanto-Mediterranean distribution. It is a common component of the lower fringe of the circalittoral twilight environment, where hard substrata are available. A. subpinnata is generally present as single or sparse specimens although some large groups of colonies were recorded (Bo et al. 2008).

Here we describe one of the most extensive populations of Antipathella subpinnata ever recorded in the Mediterranean Sea, forming a large mixed assemblage with some species of sea fans in the waters off the village Favazzina at the northern entrance of the Messina Strait (Tyrrhenian Sea). The objective of our study was 
to describe the structure, density, extension and epibiontic assemblages of the Favazzina populations of Antipathella subpinnata. Our data help to describe the marine biodiversity of deep Calabrian coastal waters, one of the least studied areas of the Mediterranean Sea.

\section{MATERIALS AND METHODS}

Study area. The study area is near the Calabrian coast between the villages of Scilla and Favazzina at the northern entrance of the Messina Strait in the Tyrrhenian Sea (Fig. 1). This site was selected on the basis of a previous survey conducted in the shallower limit of distribution (50 to $60 \mathrm{~m}$ ) of Antipathella subpinnata (Bo et al. 2008). The northern part of the Strait is oriented NE-SW and is characterised by a group of exposed rocky pinnacles emerging from a seabed of coarse sand and gravel (Santoro et al. 2002).

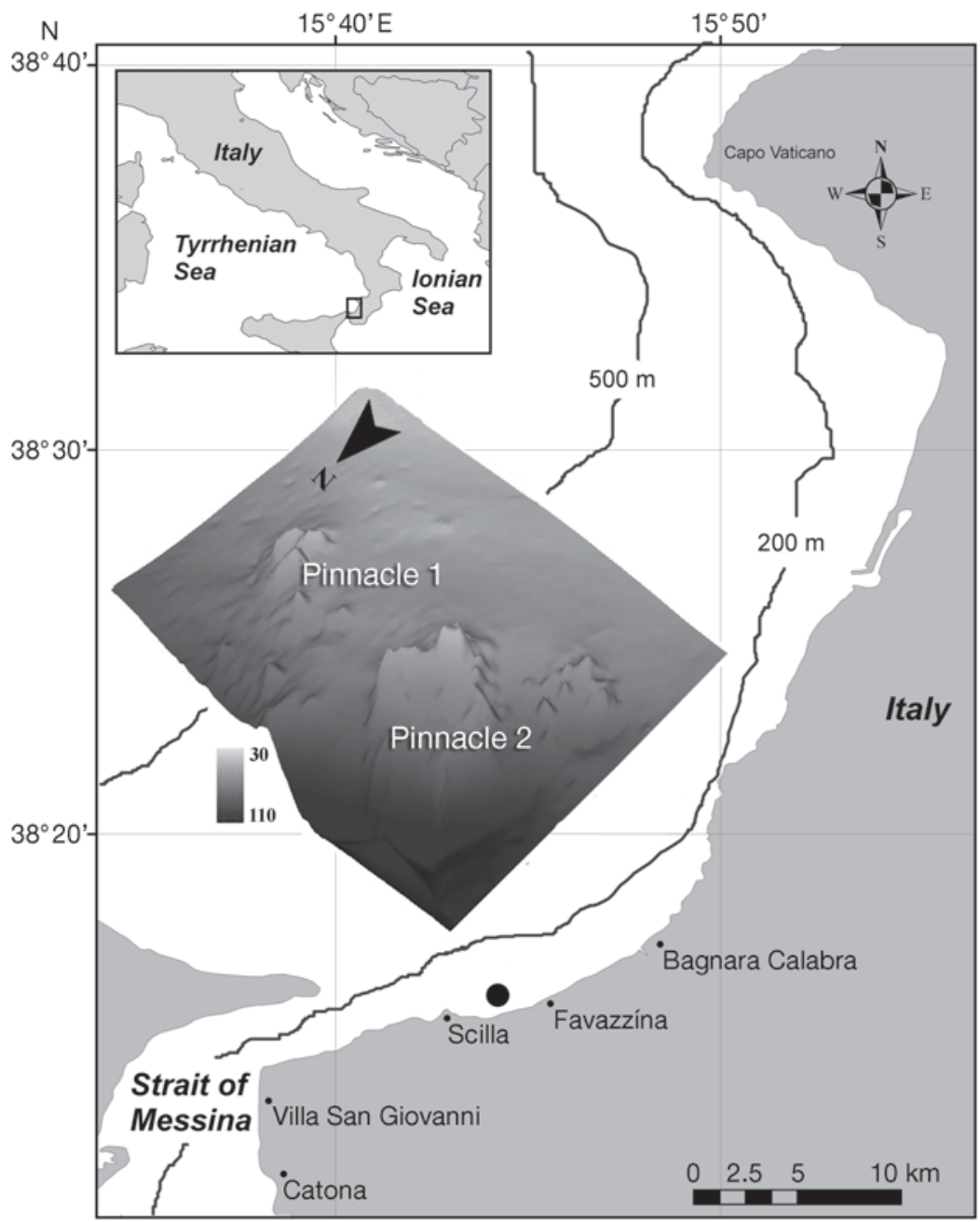

Fig. 1. Sampling site at the north entrance of Messina Strait off Favazzina village (@). Inset (note inverted north direction) showing multibeam bathymetry of Pinnacles 1 and 2. The grey scale corresponds to the depth in $\mathrm{m}$
The bathymetric data, acquired with a multibeam echo sounder (Reson SeaBat 8125), were used to create bathymetric maps and to describe the seabed topography.

Two pinnacles, located $0.4 \mathrm{n}$ miles from the coast (Fig. 1), have been explored by ROV survey in July 2008 on-board the RV 'Astrea' of the Institute for Environmental Protection and Research (ISPRA). Both video transects and photographic sampling were carried out between 50 and $100 \mathrm{~m}$ depth around the pinnacles (Fig. 2a). Pinnacle 1 (38 $15^{\prime} 45.44^{\prime \prime} \mathrm{N}$, $15^{\circ} 44^{\prime} 19.25^{\prime \prime} \mathrm{E}$, surface area about $13500 \mathrm{~m}^{2}$ ) is characterised by a group of 3 minor peaks, the tops of which are around $50 \mathrm{~m}$ depth and the bottoms around $70 \mathrm{~m}$ depth. The slopes of these peaks are scattered with rocks of various sizes alternating with patches of coarse detritic sand, with a flat detritic bottom. The top of Pinnacle $2\left(38^{\circ} 15^{\prime} 45.47^{\prime \prime} \mathrm{N}, 15^{\circ} 44^{\prime} 5.43^{\prime \prime} \mathrm{E}\right.$, surface area about $18000 \mathrm{~m}^{2}$ ) reaches $45 \mathrm{~m}$ in depth; its eastern side, directed towards the shore, gently levels off at $58 \mathrm{~m}$ depth on a sea bottom composed of detritic sediment, whereas the western rocky wall, directed towards the open sea, drops away to depths of $110 \mathrm{~m}$ onto a coarse sandy bottom (Fig. 1). There is a prevailing $\mathrm{S}-\mathrm{N}$ current arriving from the Messina Strait (Vercelli 1925, Castaldini \& Franzini 1979, Santoro et al. 2002).

Data acquisition and analysis. Two tracks, one for each pinnacle, were video-recorded with the observer class ROV 'Pollux' (Global Electric Italiana), operating at different depth ranges from their tops to their bottoms. Pinnacle 1 was divided into 2 depth ranges, 50-60 and 60-70 $\mathrm{m}$, and Pinnacle 2 into 5, 50-60, 60-70, 70-80, 80-90, 90-100 m. (Fig. 2a). This strategy was performed in order to describe the distribution and depth limits of the corals.

The ROV was equipped with an underwater acoustic tracking position system (Tracklink 1500 MA, LinkQuest), providing detailed records of the track along the seabed. Tracks were $1595 \mathrm{~m}$ (Pinnacle 1) and $1064 \mathrm{~m}$ (Pinnacle 2) in length. The video record $(3 \mathrm{~h})$ totaled to $2.7 \mathrm{~km}$, covering an area of ca. $5400 \mathrm{~m}^{2}$.

The ROV, moving $\sim 1.5 \mathrm{~m}$ above the seabed, was equipped with a digital camera (Nikon D80, 10 megapixel), an underwater strobe (Nikon SB 400), a high-definition video camera (Sony 

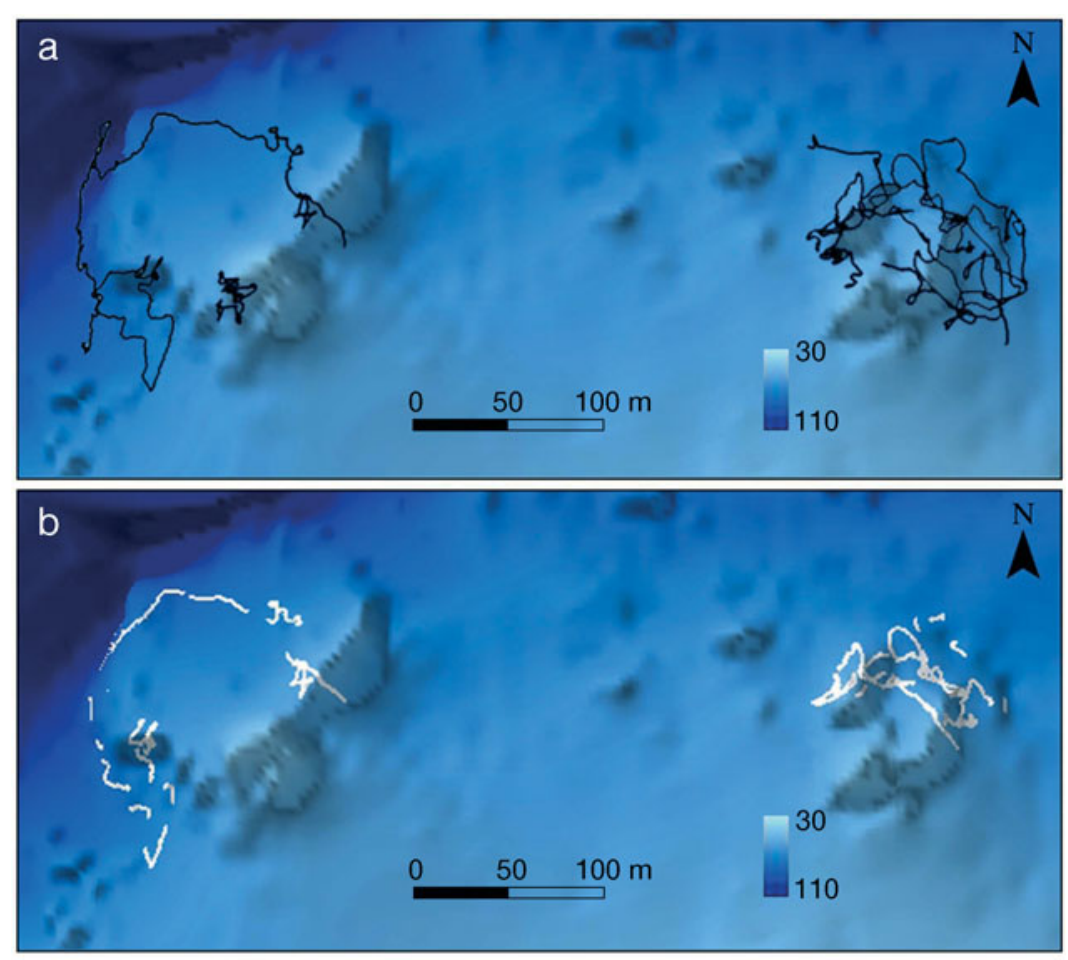

Fig. 2. (a) ROV tracks on the 2 pinnacles. (b) Highlighted portions of the tracks where black corals were observed. The colour scale corresponds to the depth in $\mathrm{m}$

to $185 \mathrm{~m}$ (Pinnacle 1) and $145 \mathrm{~m}$ (Pinnacle 2), i.e. an analyzed area of ca. $650 \mathrm{~m}^{2}$. Multibeam data were converted to a raster surface and used to create 3-dimensional georeferenced distribution maps of Antipathella subpinnata in relation to the slope of the substratum, which is the maximum rate of change between each cell of the output raster and its neighbors. The output slope raster was calculated in degrees, from $0^{\circ}$ (flat) to $90^{\circ}$ (vertical). Slope data were extracted and averaged for each video sequence. Density of coral colonies was estimated by dividing the number of colonies within a video sequence with the approximate area of the sequence.

The visual field of the ROV was $2 \mathrm{~m}$ when moving at a distance of $1.5 \mathrm{~m}$ from the bottom. Unfortunately, there was no practical way to continuously estimate the width of the visual field, which varied with the height above the bottom and the pitch and roll angles of the video camera lens (Mortensen \& Buhl-Mortensen 2004). However, when

HDR-HC7) and 3 jaw grabbers (SeaBotix) to take samples. Additionally, it had a depth sensor, a compass and 2 parallel laser beams providing a $10 \mathrm{~cm}$ scale.

Photo and video frames were used for different purposes on the basis of their different image resolution. High-resolution photographs (Pinnacle 1: 37; Pinnacle 2: 83) were used to estimate the size-frequency distributions of black coral colonies (6 size categories: 0-20, $20-40,40-60,60-80,80-100$ and $100-120 \mathrm{~cm}$ ) and the levels of epibiosis. Both coral colonies and their epibionts were sampled for taxonomic determination.

Density of colonies and composition of the coral communities were estimated from high-definition video records, divided into shorter video sequences (2 min on average). Only the video sequences showing scattered rocks, which are essential for coral growth, were selected, while sand patches were not considered. Moreover, video records from the southern slopes of the pinnacles (Fig. 2a), where black corals were absent, were not considered in the analysis. Geographical positions and depth were registered at the start and end of each sequence. Data obtained from the same depth interval were averaged. In total, the 2 video-recorded transects were divided into 28 sequences for analysis (14 each for Pinnacles 1 and 2). Each video sequence covered a distance of 1 to $50 \mathrm{~m}$ (average $=13 \mathrm{~m})$, estimated from the navigation data. The length of the considered video sequences totaled the visual field was checked by means of the 2 parallel laser beams, it was always between 1.8 and $2.2 \mathrm{~m}$. The error in area estimation had a small influence on the density of corals in the scale of a whole video sequence due to its compensation during navigation.

Statistical analyses were carried out to test whether there was a significant effect of depth on the density of corals in the assemblages and to test the influence of depth and size of colonies on their level of epibiosis. Data, checked with the Shapiro-Wilk's test, were not normally distributed, thus non-parametric tests, both the Kruskal-Wallis and the Mann-Whitney procedures, were applied (Sokal \& Rohlf 1981). Analyses were performed using PAST for Windows version 1.91 (Hammer et al. 2001).

\section{RESULTS}

\section{Distribution, abundance and co-occurrence of corals}

In total, 1556 coral colonies belonging to 3 species the black coral Antipathella subpinnata and the gorgonians Paramuricea clavata (Risso, 1826) and Eunicella cavolinii (Koch, 1887) - were recorded from the analyzed video sequences of the 2 tracks. Within this group, A. subpinnata was the most abundant and widely distributed species in the area $(773$ colonies, 
$\sim 50 \%$ of the total), followed by P. clavata (699 colonies, $\sim 45 \%$ of the total), which mainly occurred in the upper limit of the assemblages, and E. cavolinii (84 colonies, $\sim 5 \%$ of the total).

In Pinnacle 1, between 55 and $70 \mathrm{~m}$ depth, the most abundant species was Antipathella subpinnata (78\% of the total, 313 colonies), followed by Paramuricea clavata $(21.5 \%, 86$ colonies) and Eunicella cavolinii $(0.5 \%, 2$ colonies). In Pinnacle 2, between 55 and $100 \mathrm{~m}$, the dominant species was P. clavata $(53 \%$, 613 colonies), followed by $A$. subpinnata (40\%, 460 colonies) and E. cavolinii (7\%, 82 colonies).

The average density of the entire coral assemblage reached $2.9 \pm 0.4$ colonies $\mathrm{m}^{-2}$ with a maximum of 10 colonies $\mathrm{m}^{-2}$. The average densities for Antipathella subpinnata, Paramuricea clavata and Eunicella cavolinii, were $1.4 \pm 0.2$ (max. 5.2), $1.2 \pm 0.32$ (max. 6.8) and $0.15 \pm 0.05$ colonies $\mathrm{m}^{-2}$ (max. 1.5), respectively. The density of the assemblage reached a maximum in the shallowest part of the pinnacles and decreased regularly towards their bottom (MannWhitney, $\mathrm{p}<0.05$ for Pinnacle 1 with 2 depth ranges;
Kruskal-Wallis, $\mathrm{p}<0.01$ for Pinnacle 2 with 5 depth ranges) (Fig. 3a,b).

From the top of the 2 pinnacles down to $70 \mathrm{~m}$ depth, Antipathella subpinnata occurred in a dense mixed assemblage with Paramuricea clavata and sparse colonies of Eunicella cavolinii (Fig. 4a,b). Here the community showed the greatest average density. From 70 to $80 \mathrm{~m}$ depth, A. subpinnata was the most abundant species, while the 2 sea fans progressively disappeared (Fig. 4c). At depths $>90 \mathrm{~m}$, black corals were very rare, while the gorgonians were completely absent (Figs. 3c,d \& 4d,e).

On both pinnacles the first 2 size classes (0-20 and 20-40 cm) of Antipathella subpinnata were the most common, indicating that the population can rely on many young colonies. The number of colonies in the higher size classes progressively decreased. Highest corals (80 to $120 \mathrm{~cm}$ ) were present only between 60 and $80 \mathrm{~m}$ depth, where black corals were most abundant (Fig. 5).

Antipathella subpinnata was present on Pinnacle 1 only on the side exposed to the open sea (W-E), while it was completely absent on the southern side facing

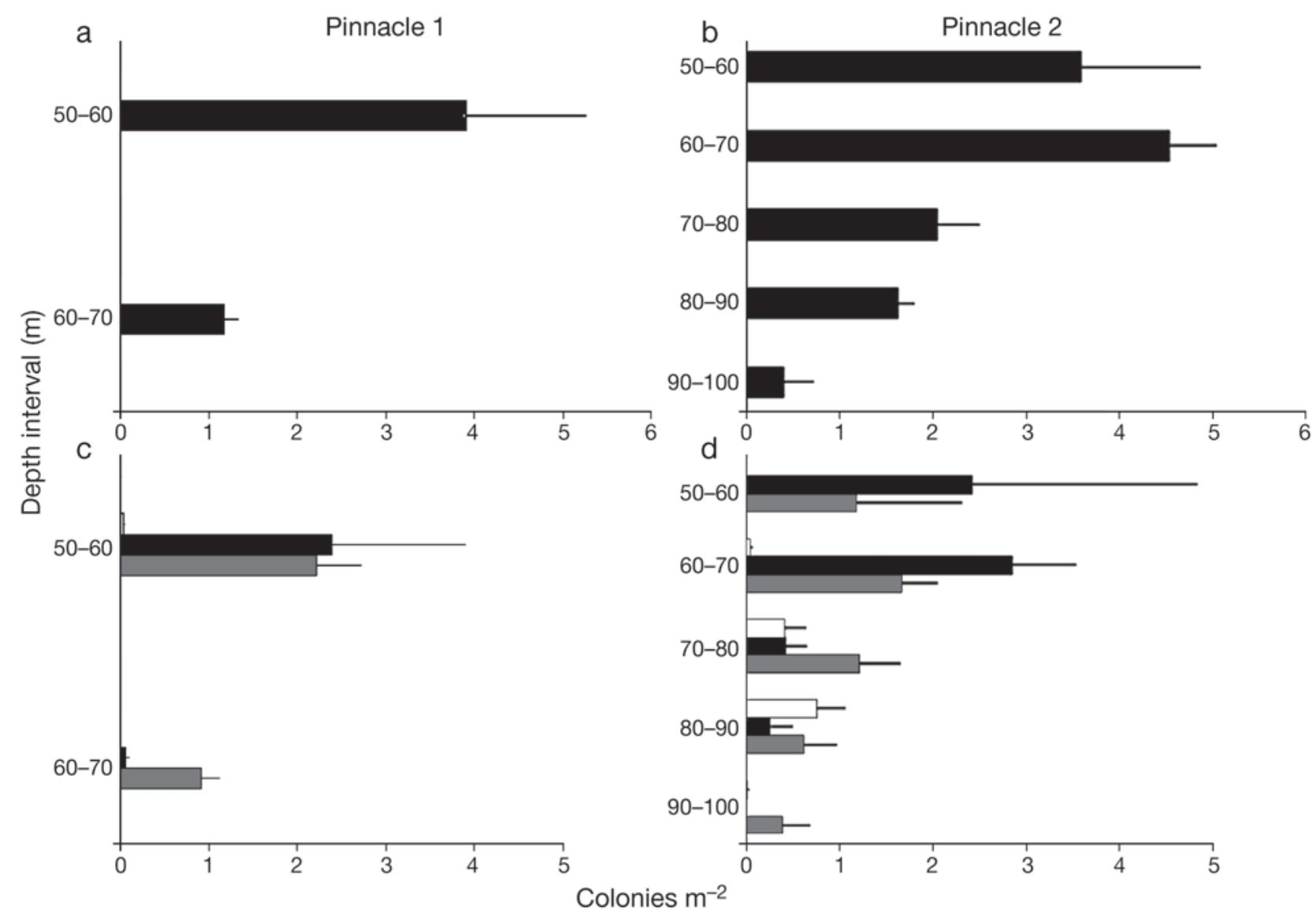

Fig. 3. Paramuricea clavata, Antipathella subpinnata, and Eucinella cavolinii. Average density ( \pm SE) of the coral community per depth interval on (a) Pinnacle 1 and (b) Pinnacle 2. Average density ( \pm SE) of corals per depth interval and species on (c) Pinnacle 1 and (d) Pinnacle 2: P. clavata (black bars), A. subpinnata (grey bars), and E. cavolinii (white bars) 
the coast. On Pinnacle 2, A. subpinnata was present on the sides facing the Strait $(\mathrm{S}-\mathrm{W})$ and exposed to the open sea, while it was missing in the S-E quadrant in front of Pinnacle 1 (Fig. 2b). Considering the surface area of the sides of the pinnacles where A. subpinnata was present and its average density, the abundance of the entire Favazzina population is estimated at several thousand colonies.
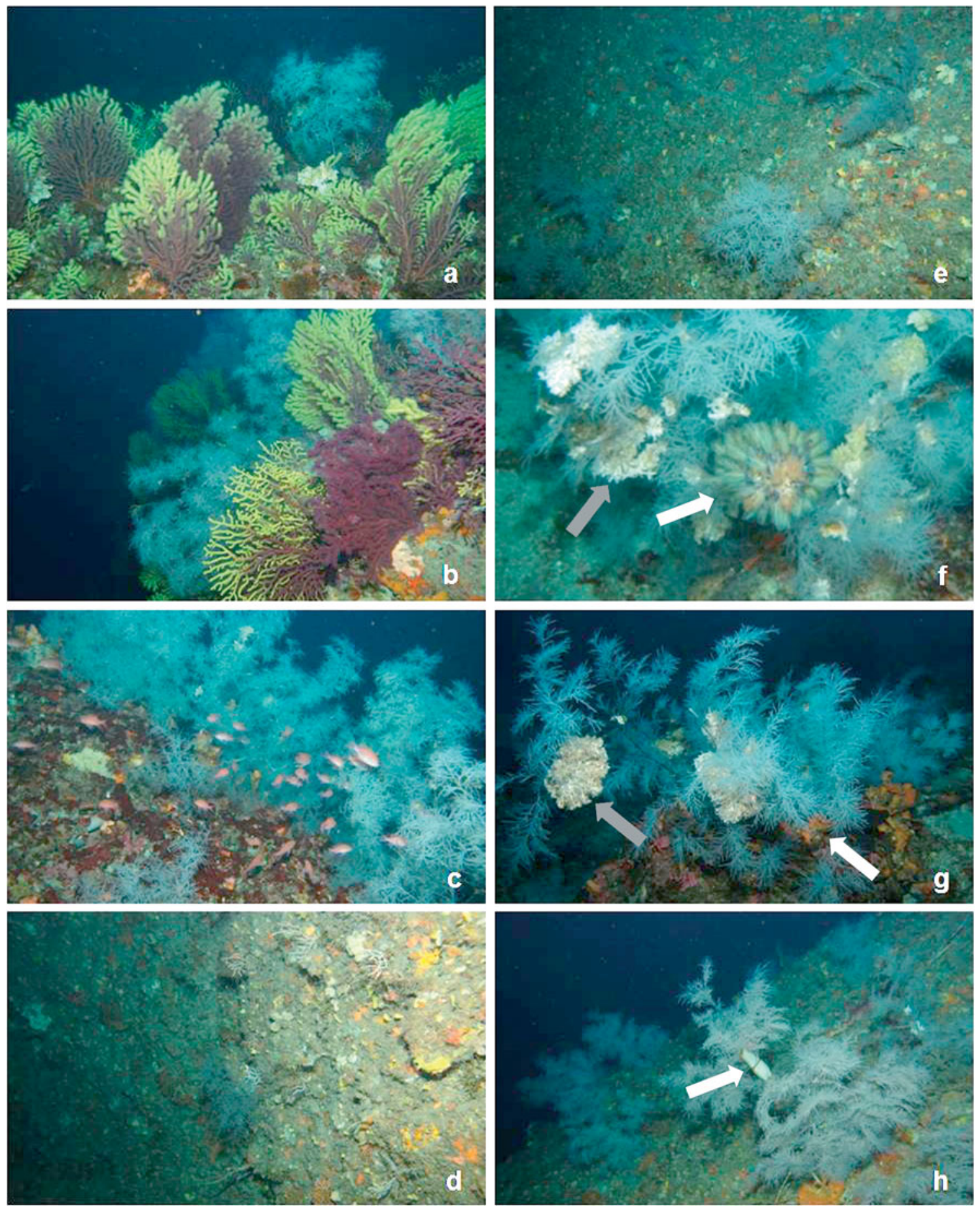

Fig. 4. Underwater photographs of Antipathella subpinnata coral meadow. Pinnacle 2 at different depth intervals. (a,b) Mixed assemblage of $A$. subpinnata and Paramuricea clavata at 50 to $60 \mathrm{~m}$ depth; (c) dense meadow of black corals at 60 to $80 \mathrm{~m}$ depth; (d,e) sparse colonies of A. subpinnata and Eunicella cavolinii at 80 to $100 \mathrm{~m}$ depth; $(\mathrm{f}, \mathrm{g})$ epibiosis on black coral colonies by (f) Clavelina dellavallei (Ascidia) (white arrow); (g) bryozoans (white arrow) and (f,g) Filograna spp. (Serpulidae) (grey arrows); (h) Scyliorhinus sp. egg hanging from a coral branch (white arrow) 
Depth is probably the main parameter influencing the density of Antipathella subpinnata colonies; and substrate slope likely affects colony settlement and growth. In fact, a wider range of colony density was observed along slight slopes $\left(0\right.$ to $30^{\circ}$ ), while colony density was always low when the inclination increased (30 to $\left.60^{\circ}\right)$ (Fig. 6).
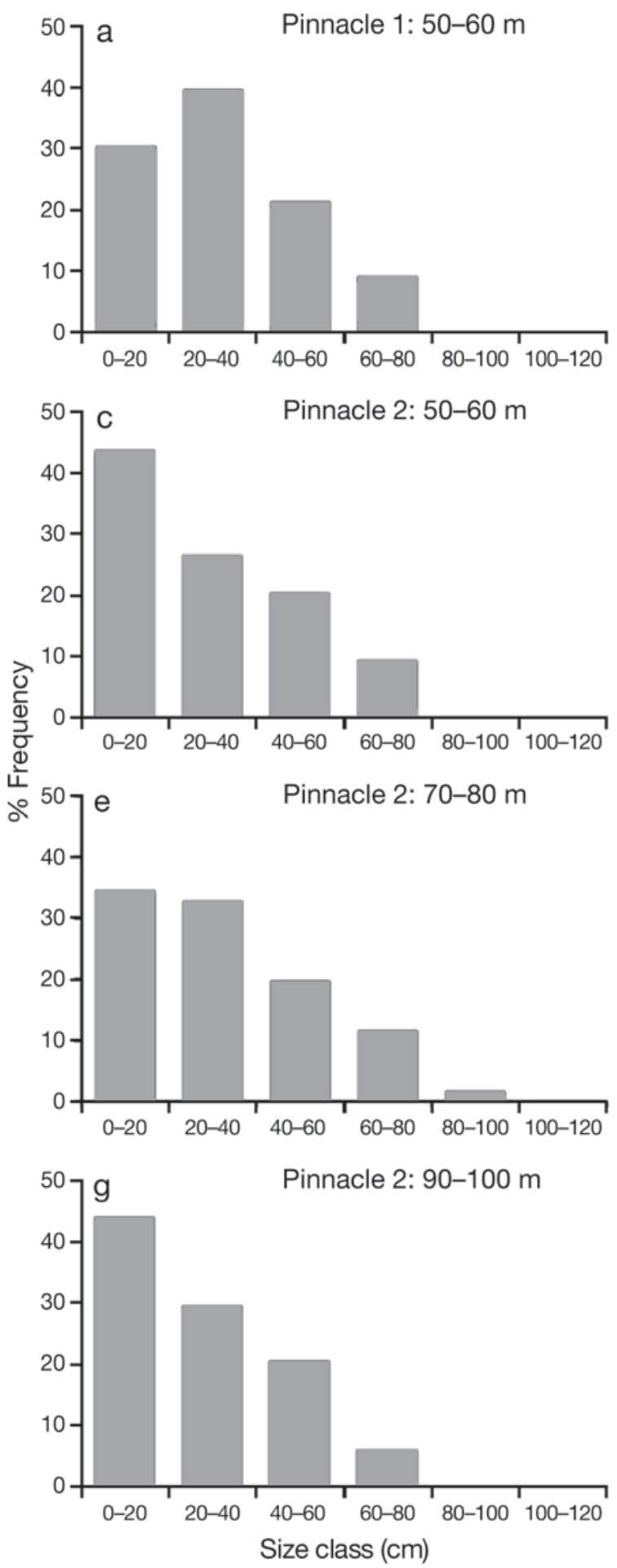

\section{Epibiosis}

The colonies of Antipathella subpinnata are known to host several species of epibionts generally settling in large masses on the branches (Bo et al. 2008) (Fig. $4 \mathrm{f}-\mathrm{h})$. The most common species recorded during the present study were the serpulid Filograna spp. (75
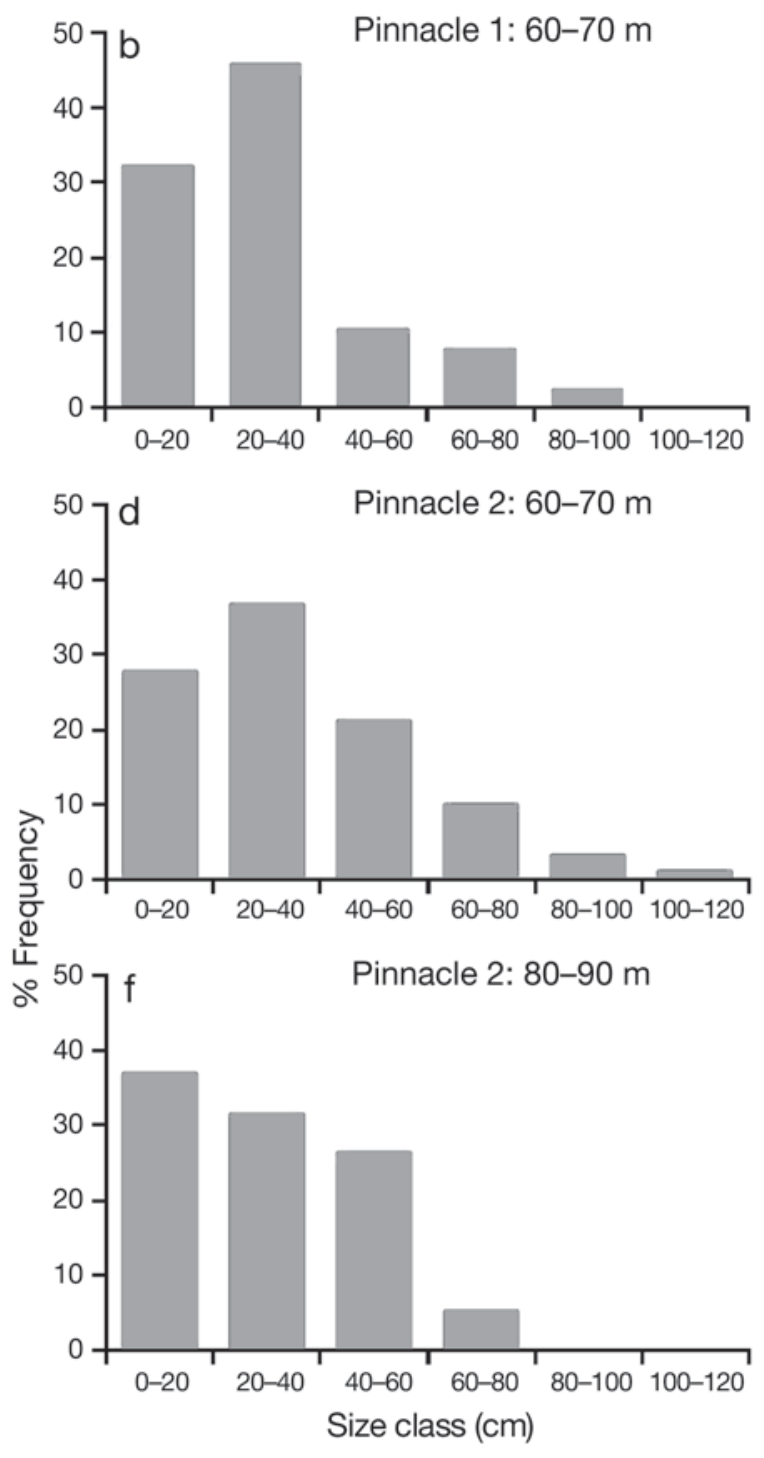

Fig. 5. Antipathella subpinnata. Size-frequency distributions of colonies at the investigated depth intervals for $(a, b)$ Pinnacle 1 and $(\mathrm{c}-\mathrm{g})$ Pinnacle 2 
colonies), the bryozoans Schizobrachiella sanguinea (Norman, 1868) and Pentapora fascialis (Pallas, 1766) (19 colonies) and the ascidian Clavelina dellavallei (Zirpolo, 1825) (12 colonies) (Fig. 7). Epibionts were present both on live sections of colonies (especially Filograna spp. and C. dellavallei) and dead branches of live corals (bryozoans and sponges). Scyliorhinus sp. eggs are occasionally observed on A. subpinnata (Fig. 4h).

About 44 and $24 \%$ of the total observed black coral colonies on Pinnacle 1 and 2, respectively, hosted epibionts; however, these values significantly decreased with depth and increased with the size of the coral colonies (Mann-Whitney, $\mathrm{p}<0.05$ for Pinnacle 1 with 2 depth intervals; Kruskal-Wallis, $\mathrm{p}<0.01$ for Pinnacle 2 with 5 depth intervals) (Fig. 8).

\section{DISCUSSION}

Suspension feeder communities play an important role in the pelagic-benthic transfer of energy and biomass. In particular, corals are of crucial importance in sublittoral temperate assemblages, where they occur on hard substrata in scarcely illuminated environments washed by strong currents (Gili \& Coma 1998). In the Mediterranean Sea, these communities are mainly studied in shallow waters, and few data are available for deep environments. Our data show that dense coral meadows are present in the central Mediterranean sea at depths down to $100 \mathrm{~m}$.

While the diversity of Mediterranean black coral species is well known, data about their ecology are very scarce. due to the almost complete absence of

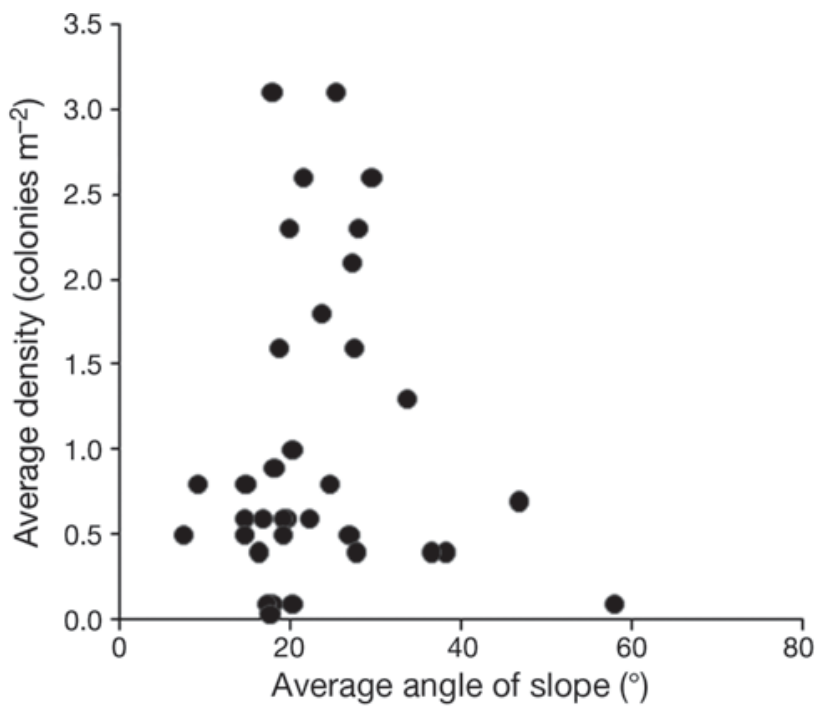

Fig. 6. Antipathella subpinnata. Relationship between average colony density and average slope inclination in each video sequence analyzed for the 2 pinnacles

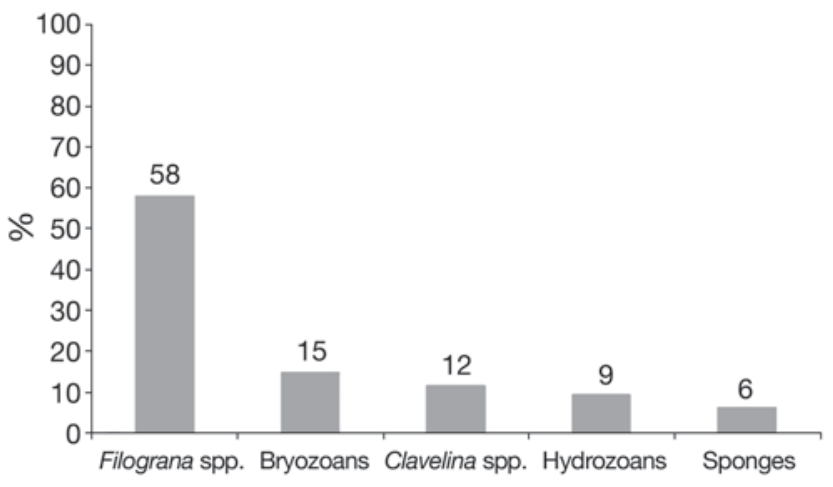

Fig. 7. Epibionts on black corals of the Favazzina pinnacles. Main taxa in \%

field studies (Opresko \& Försterra 2004). The only exception is Antipathella subpinnata (Bo et al. 2008), for which a list of records allowed the basic description of the ecological requirements. The data presented here allow a more detailed description of the habitat of this species and its population structure.

The Favazzina coral meadow is probably due to the hydrodynamic conditions of the Messina Strait (Vercelli 1925, Castaldini \& Franzini 1979). In this area, the main current runs deep from south to north while a weaker superficial current flows in the opposite direction (Santoro et al. 2002). The studied pinnacles are located almost on the edge of the continental shelf, exposing their northern slopes to the prevailing current. This could explain the orientation of the black coral populations (Fig. 2b), indicating that, relative to the gorgonian Paramuricea clavata, Antipathella subpinnata seems to be more adapted to strong currents: its resistant and flexible chitinous skeleton is particularly suitable for living in strongly moving water.

The relationship of black coral assemblages with strong currents has already been observed along the slopes of north Pacific seamounts, which produce upwelling currents. These currents supply resuspended organic matter from the seabed to the suspension feeding corals (Genin et al. 1986, Kaufmann et al. 1989).

The 2 explored pinnacles are similar in their cooccurrence of corals, as shown by the community structure, indicating specific bathymetric ranges with partial overlaps for Antipathella subpinnata and the 2 sea fan species Paramuricea clavata and Eunicella cavolinii. The differences in distribution are mainly related to the different bathymetric ranges of each pinnacle, allowing Pinnacle 2, reaching $100 \mathrm{~m}$ in depth, to host a more complex assemblage.

Temperature variations of the superficial Mediterranean waters, subjected to a seasonal cycle, likely confine Antipathella subpinnata to depth below $50 \mathrm{~m}$ 

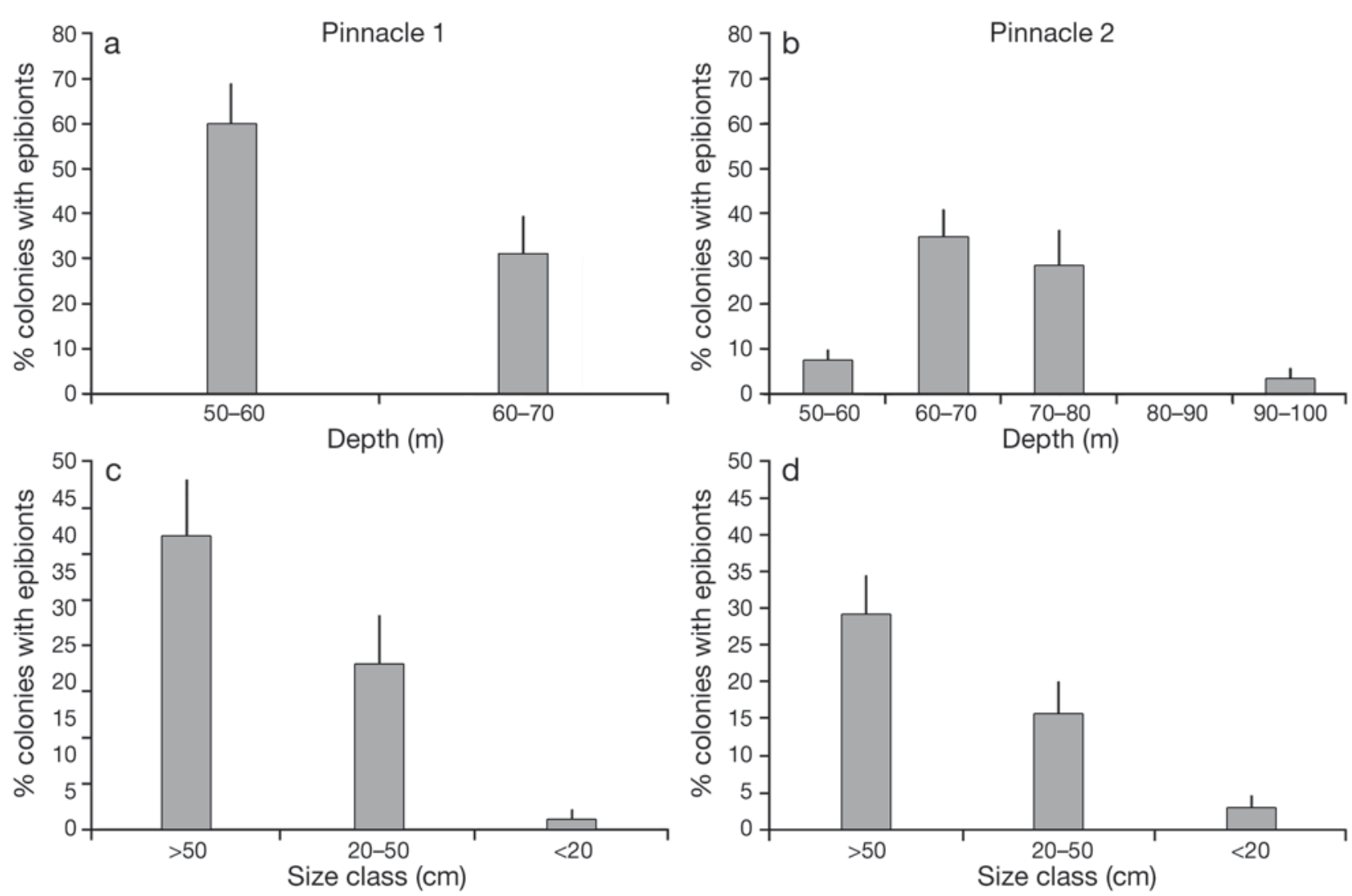

Fig. 8. Antipathella subpinnata. Percentage of colonies with epibionts in each (a,b) depth interval and (c,d) size class on Pinnacle 1 and Pinnacle 2, respectively

(Bo et al. 2008). The present study of the Favazzina coral meadow suggests that the lower bathymetric limit for this species is about 90 to $100 \mathrm{~m}$ in depth. These data agree with observations in the northern Mediterranean Sea indicating that A. subpinnata must be considered a typical element of the lower fringe of the circalittoral assemblage, where it gradually replaces the purple sea fan Paramuricea clavata which dominates the coral community down to $50 \mathrm{~m}$ (G. Bavestrello unpubl. data). Records of A. subpinnata below $100 \mathrm{~m}$ can be considered occasional (Bo et al. 2008).

Monospecific meadows of branched antipatharians are very rarely recorded in temperate and cold waters. The only other known case is the congeneric species Antipathella fiordensis (Grange 1990), recorded between 5 and $35 \mathrm{~m}$ depth in the southern fiords of New Zealand (Grange 1985, 1988, 1990, Grange \& Singleton 1988). The Tethyan relict distribution of the genus Antipathella has already been suggested (Bo et al. 2008), but the present data indicate that A. fiordensis and $A$. subpinnata also share a similar ecology. The New Zealand populations show an average density of 0.25 colonies $\mathrm{m}^{-2}$ (up to 5 colonies $\mathrm{m}^{-2}$ ), while in Favazzina the average density of $A$. subpinnata is
1.4 colonies $\mathrm{m}^{-2}$ (up to 5.2 colonies $\mathrm{m}^{-2}$ ). Moreover, the size-frequency distributions of the populations of the 2 species are very similar, with the smaller size-classes being the most represented in both cases. New Zealand black coral colonies, as those in Favazzina, tend to prefer faster currents, but inhabit steeper slopes thus avoiding detritus rolling down the fiord (Grange 1985, 1988, 1990, Grange \& Singleton 1988).

The Favazzina population is found on rocky pinnacles unsuitable for commercial trawling. However, as previously suggested for sea fans (Bavestrello et al. 1997), it is possible that the susceptibility of Antipathella subpinnata to epibiosis may be enhanced by mechanically injuring the colonies coenenchyme, e.g. by longline fishing. It is therefore important to extend the lower depth limit of Mediterranean Marine Protected Areas to preserve the integrity of these deep coral meadows.

Acknowledgements. This study was conducted by the Istituto Superiore per la Protezione e la Ricerca Ambientale (ISPRA formerly ICRAM), within project no. 327 MoBioMarCal, and financed by the Calabrian Regional Council for Environment. The work undertaken through MoBioMarCal is affiliated to the European Census of Marine Life. Authors thank the crew of RV 'Astrea' for the enormous help during the campaings and Dr. Maio Mori for his help in the data analysis. 


\section{LITERATURE CITED}

Bavestrello G, Cerrano C, Zanzi D, Cattaneo-Vietti R (1997) Damage by fishing activities to the gorgonian coral Paramuricea clavata in the Ligurian Sea. Aquat Conserv 7: 253-262

Bo M, Tazioli S, Spanò N, Bavestrello G (2008) Antipathella subpinnata (Antipatharia, Myriopathidae) in Italian seas. Ital J Zool 75:185-195

Castaldini M, Franzini L (1979) On the currents in the Messina Strait linear and nonlinear tidal components on the sill. Nuovo Cimento C 2:569-584

Genin A, Dayton PK, Lonsdale PF, Spiess FN (1986) Corals on seamount peaks provide evidence of current acceleration over deep-sea topography. Nature 322:59-61

Gili JM, Coma R (1998) Benthic suspension feeders: their paramount role in littoral marine food webs. Trends Ecol Evol 13:316-321

Grange KR (1985) Distribution, standing crop, population structure, and growth rates of black coral in the southern fiords of New Zealand. NZ J Mar Freshw Res 19:467-475

Grange KR (1988) Redescription of Antipathes aperta, Totton (Coelenterata: Antipatharia), an ecological dominant in the southern fiords of New Zealand. NZ J Zool 15:55-61

Grange KR (1990) Antipathes fiordensis, a new species of black coral (Coelenterata: Antipatharia) from New Zealand. NZ J Zool 17:279-282

Grange KR, Singleton RJ (1988) Population structure of a black coral, Antipathes aperta, in the southern fiords of New Zealand. NZ J Zool 15:481-489

Hammer Ø, Harper DAT, Ryan PD (2001) PAST: paleontological statistics software package for education and data

Submitted: February 24, 2009; Accepted: June 26, 2009 analysis. Palaeo Elec 4:1-9, available at http://palaeoelectronica.org/2001_1/past/issue1_01.htm

Kaufmann RS, Wakefield WW, Genin A (1989) Distribution of epibenthic megafauna and lebensspuren on two central North Pacific seamounts. Deep-Sea Res A 36: 1863-1896

Mortensen PB, Buhl-Mortensen L (2004) Distribution of deepwater gorgonian corals in relation to benthic habitat features in the Northeast Channel (Atlantic Canada). Mar Biol 144:1223-1238

Opresko DM, Försterra G (2004) Orden Antipatharia (corales negros o espinosos). In: Hofrichter R (ed) El Mar Mediterraneo: fauna, flora, ecologia, Vol 2. Omega, Barcelona, p 506-509

Santoro VC, Amore E, Cavallaro L, Cozzo G, Foti E (2002) Sand waves in the Messina Strait, Italy. J Coast Res SI36: 640-653

Sokal RR, Rohlf FJ (1981) Biometry. The principle and practice of statistics in biological research. WH Freeman and Company, New York

Taviani M, Freiwald A, Zibrowius H (2005) Deep coral growth in the Mediterranean Sea: an overview. In: Freiwald A, Roberts JM (eds) Cold-water corals and ecosystems. Springer-Verlag, Berlin/Heidelberg, p 137-156

Tursi A, Mastrototaro F, Matarrese A, Maiorano P, D'Onghia G (2004) Biodiversity of the white coral reefs in the Ionian Sea (Central Mediterranean). Chem Ecol 20:107-116

Vercelli F (1925) Crociere per lo studio dei fenomeni dello Stretto di Messina. I. Il regime delle correnti e delle maree nello Stretto di Messina. Commissione Internazionale del Mediterraneo, Off. Grafiche Ferrari, Venezia

Proofs received from author(s): November 5, 2009 